\title{
The Obstacles for the Teaching of 8th Grade TR History of Revolution and Kemalism Course According to the Constructivist Approach (An Example of Exploratory Sequential Mixed Method Design)
}

\author{
Yavuz Karademir, Selcuk Besir Demir
}

Division of Social Studies Education, Department of Elementary Education, Faculty of Education, Sivas Cumhuriyet University, Turkey

Copyright (C) 2015 by authors, all rights reserved. Authors agree that this article remains permanently open access under the terms of the Creative Commons Attribution License 4.0 International License

\begin{abstract}
The aim of this study is to ascertain the problems social studies teachers face in the teaching of topics covered in 8th grade TRHRK Course. The study was conducted in line with explanatory sequential mixed method design, which is one of the mixed research method, was used. The study involves three phases. In the first step, exploratory process was followed, in the second step measurement tool was developed and in the third step the measurement tool was applied to the sample chosen from the universe. In this study, data collection process was realized in two steps. In the first step, qualitative data were collected and later on quantitative data were collected using quantitative measurement tool, which was developed based on qualitative data and then validated. The qualitative study group of the research was determined using criterion sampling, which is one of the purposeful sampling methods. The quantitative study group was determined via double (two-phase) cluster sampling method. In line with the responds provided by the participants, qualitative findings were categorized and presented as 3 themes: (i) inadequacy of course time and the problems caused by intensive content, (ii) adoption of Behaviorist Approach as opposed to constructivism, (iii) Problems caused by perception, attitude towards the course and other factors. Following from this, 23 -item quantitative measurement tool was developed and administrated on the qualitative sample of the study composed of 1090 social studies teachers working in 28 cities. Quantitative data indicated that qualitative data can be generalized. As a result, even if the education program of TRHRK is designed according to constructivist approach, traditional, teacher-centered history education based on memorization is continued because of the obstacles defined in the current study.
\end{abstract}

Keywords TR History of Revolution and Kemalism, the Constructivist Approach, Ideology and History, Problems

\section{Introduction}

As a result of reformist efforts in 2005 in Turkey, the education programs for all elementary education courses were prepared and applied based on constructivist approach $[27,52,58]$. In new education programs adopted by MNE, it is seen that a new "student-centered understanding balancing information and skill, enabling students to communicate with their environments and considering students' own lives and individual differences" was adapted $[7,9,10,19,25,46$, $58,74]$.

One of the courses which were most sensitively and critically affected from the amendments in educational programs are history courses $[3,26,41]$. As history course fulfills the function of transmitting the citizenship identity and acculturation, the changes made in the educational program of this course will directly affect the characteristics of citizens to be raised as next generations. In this context, changes were made in the Education Program in Turkish Republic History of Revolution and Kemalism (TRHRK) course, the aim of the course was determined as: "to raise Turkish youth who grasp and develop Atatürk's Revolution, Atatürk's System of Thought, the spirit and aims of Turkish Revolution; and citizens who know their rights and responsibilities towards their state and nation, and to enable them acquire the understanding of the Independence of Turkish Nation, patriotism, national unification" $[8,77]$. On the one hand, with its historical dimensions TRHRK course develop cognitive skills and give learners chances to understand the events in the past and today, learn and assess the reasons and results of the events in recent Turkish history, in other words to understand and assess this period as a whole and develop historical understanding; on the other hand, with its ideological dimension the course can realize the integration of individuals with existing political and public life by enabling them to grasp the fundamentals of political and social structure [37]. 
As defined above, examination of the problems social studies teachers face in a course which has an important mission and objectives is important. In this context, studies were carried out on various aspects of $8^{\text {th }}$ Grade TRHRK course. For example, in a study by Camkıran [15], teachers expressed their discomfort with the inadequacy of information in textbooks; Adalar [2] concluded that physical conditions made it difficult to reach the attainments in the education program. In other studies, it was determined that social studies teachers face various problems related to the social and physical conditions of the environments of the schools, the inadequacy of the sources in the education environment, administrators, teachers, students and parents and these problems were all related to each other. They also found that there was not enough time to over the syllabus; therefore, some activities in the constructivist approach could not be applied $[2,8,24]$. The studies in the literature carried out quantitative studies which do not examine the causes of the problems in depth. When the developments with regard to these courses are considered together with these studies, it is seen that the syllabus was arranged according to constructivist approach and weekly hour of the TRHRK course was increased from 2 to 3 as of 2008-2009 educational year. As of 2010 and 2011 educational year, the topics in recent period were added and the weekly hours of the course was decreased from 3 to 2 .

In the face of the changes in education program as of 2005 and the deficiencies emphasized in education program, the problems social studies teachers face in TRHRK course are to be examined in detail and determined. Especially, the matters that obstruct the application of constructivism on which the program is based are to be determined.

Following from here, the aim of this study is to determine the problems social studies teachers encounter in the teaching of TRHRK course and to examine the reasons of these problems in depth, to convert the results obtained with qualitative research method into a quantitative measurement tool and in turn to determine if these problems can be generalized to the universe of social studies teachers in Turkey. For these reasons, this study is significant in that it determines the situations with regard to the problems encountered and create a perspective for the future.

\section{Method}

\subsection{The Design of the Study}

This study was carried out in line with mixed method approaches. In the study, "exploratory sequential method", which is one of the mixed method designs, was used. Exploratory sequential method is a design in which the researcher starts with exploring qualitative data and then uses these findings in quantitative research stage [20]. In exploratory sequential mixed method design as in explanatory sequential mixed method, the second data base is founded upon findings of in initial data base. The aim of exploratory sequential mixed method is to develop better methods for measurement for a specific universe and to see whether data obtained from a few individuals (in the qualitative dimension) can be generalized to the universe [20]. The study has three stages. In the first stage is exploratory stage, in the second stage the measurement tool was developed and in the third stage the measurement tool was applied on the sample from the universe.

\subsection{Process}

In this study, data was collected in two stages. In the first stage qualitative data were collected and later on a quantitative measurement tool was designed based on qualitative data and quantitative data were collected with this quantitative measurement tool for which necessary validation analyses were made. The qualitative data obtained in the first stage was used to develop a measurement tool with good psychometric characteristics. The researcher analyzed two databases separately and the findings obtained from qualitative database were used to make quantitative measurements.

During the study, sequential timing was followed and the collection and analysis of qualitative data was prioritized. Based on the results explored, the researchers passed on the quantitative stage and preliminary results were tested to test or assess qualitative exploratory findings. The first stage of the study was carried out with a constructivist point of view and the second stage was carried out with post-positivist view and an interactive and sequential procedure with emphasis on qualitative data.

The researchers analyzed the two data bases separately and used the findings obtained from exploratory database to create quantitative measurements. The findings of the mixed method have been interpreted in the discussion section. First of all qualitative findings, the use of qualitative findings (development of a measurement tool, development of new quantitative measurements etc.) were reported and later on quantitative findings were reported. According to Morse [61], the research process can be symbolized as follows QUALITATIVE $\rightarrow$ quantitative. The research process was designed according to Myers and Oetzel [62] and Creswell and Pablo-Clark [21] and presented in detail in Figure 1. 


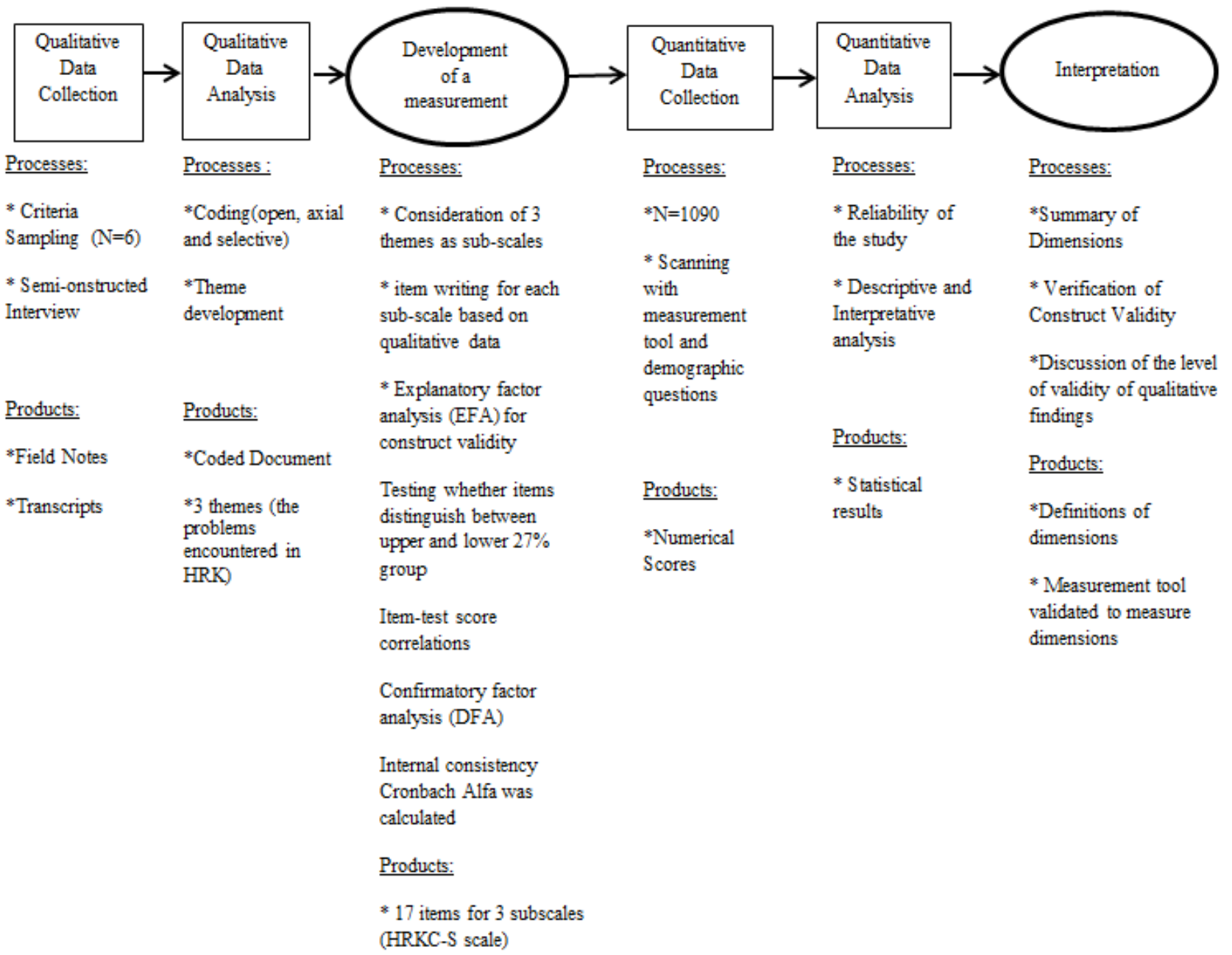

Figure 1. Schematic Presentation of the Research Process

Table 1. Detailed Information about the Participants

\begin{tabular}{|c|c|c|c|c|c|}
\hline Nickname & Gender & Branch & Department Graduated & Length of Service(Year) & Place of Duty \\
\hline P1 & Male & Social studies & Social studies education & 11 & Town(Affiliated with a County) \\
\hline P2 & Female & Social studies & Social studies education & 14 & Town(Affiliated with a County) \\
\hline P3 & Male & Social studies & Social studies education & 7 & City Center \\
\hline P4 & Female & Social studies & Social studies education & 6 & City Center \\
\hline P5 & Male & Social studies & Social studies education & 7 & County Seat \\
\hline P6 & Female & Social studies & Social studies education & 13 & County Seat \\
\hline
\end{tabular}

\subsection{Qualitative Phase}

\subsubsection{Participants}

The focus group interview in the first phase of the study was made with social studies teachers in Sivas province. The study group is composed of 6 teachers ( 3 female and 3 male) working in state schools. The service lengths of the participants ranged between 6 to 14 years. To determine the study group, criteria sampling method, which is one of the purposeful sampling methods, [66] was used. While the study group was being determined according to criteria method, social studies teachers with at least 6 years of service length was chosen considering that they had experienced the changes in education programs and in the course time. This was the essential criterion because 8th grade TRHRK was recharged and the weekly hour of the course was increased from 2 to 3 hours. As of 2010 and 2011 educational year, topics of the recent period were added but the number of the weekly hours of the course decreased from 3 to 2 hours. Accordingly, the participants were chosen from teachers who had been teaching TRHRK course before and after changes. In the study, the participants were informed about the study beforehand and volunteerism was adopted as participation criterion because of ethical concerns. The names of the participant teachers were not used and they were nick named from P1 to P6. 


\subsubsection{Qualitative Data Collection Tool}

\subsubsection{Qualitative Phase}

In this study, "Semi-structured Interview Form", which is one of the qualitative study methods, was used. Semi-structured interview technique seems to be a more suitable technique for research as it has certain level of standardization and flexibility as well $[66,89]$.

Before interview questions were prepared, the table showing "Units, Number of Attainments, Number of Hours and Rates", which has been recreated after the weekly hour of TRHRK course was decreased from 3 hours to 2 hours was examined carefully. The number of the course hours was decreased according to the Primary Aims of Turkish National Education and the Fundamental Turkish National Education Law no. 1739 and according to the decisions made by Board of Education and Discipline after 2008 and particularly the decision taken by the board on 20.07.2010 with decision no. 75 . The studies in the literature on 8th Grade TRHRK course $[2,8,15,24,58]$ were examined, and as a result of the examinations draft interview form was developed. The questions in the draft interview form were examined in detail by a faculty who is expert in qualitative research methods. In line with expert views, interview questions were reshaped.

The drafted interview form was piloted with two Social studies teachers who started working before 2008 and experienced the amendments made in the course to test the quality and adequacy of the questions in the interview form. The teachers who took part in the pilot application were not included in the qualitative study group. As a result of pilot application, it was determined that there was not any problem with the questions in the interview.

All questions in the interview form were put to the participants. Different questions were also asked to analyze answers in depth. In general, the participants were asked questions about the sufficiency of weekly hours of the course for the attainments in TRHRK course, about the methods and techniques used in TRHRK course, physical conditions, learning environment, students and parents of the students. Data with regard to the study were collected in a silent environment, which would not disturb the interviews. The interviews were made in January 2014. Interviews which last a total of $221 \min 34$ second were made. The participants were given information about the aim of the study and they were ensured that personal information will be kept confidential.

\subsubsection{Interpretation of Qualitative Data Analysis}

\subsubsection{Analysis of Qualitative Data}

\subsection{Interview Transcriptions}

All interviews made with the study group were recorded via voice recorder device. The data recorded were transformed into raw data as written texts via Microsoft Word processor and these transcriptions were presented to the participants one by one and it was confirmed that these texts comply with what they said.

\subsection{Data Coding}

Before data were coded, the researchers read the transcriptions line by line. Meanwhile, important dimensions in the framework of the study were determined and the meaning of each dimension was described. The words and concepts used by the participants were used in coding as much as possible. However, when the words and concepts participants use were inadequate other concepts which were considered to express the relevant case or opinion, were determined as codes by the researchers. In data coding, line by line analysis method defined by Patton [66] was used. A word, word groups or a sentence was used as units for data analysis. In coding process, axial and selective coding techniques were used.

\subsection{Interpretation Techniques}

For the interpretation of interview data, inductive descriptive analysis, content analysis and constant comparison techniques were used $[56,60]$. In descriptive analysis, direct quotations from the participants were used frequently to express the participants dramatically. In content analysis, data were divided into sections and these sections were examined and compared. Later on, important concepts were created from these sections and the codes that evoke the same concepts were brought together under a common category. In the final stage, meaning unity was achieved based on themes emerging from data. The relation between themes and data obtained is presented in Figure 2. 


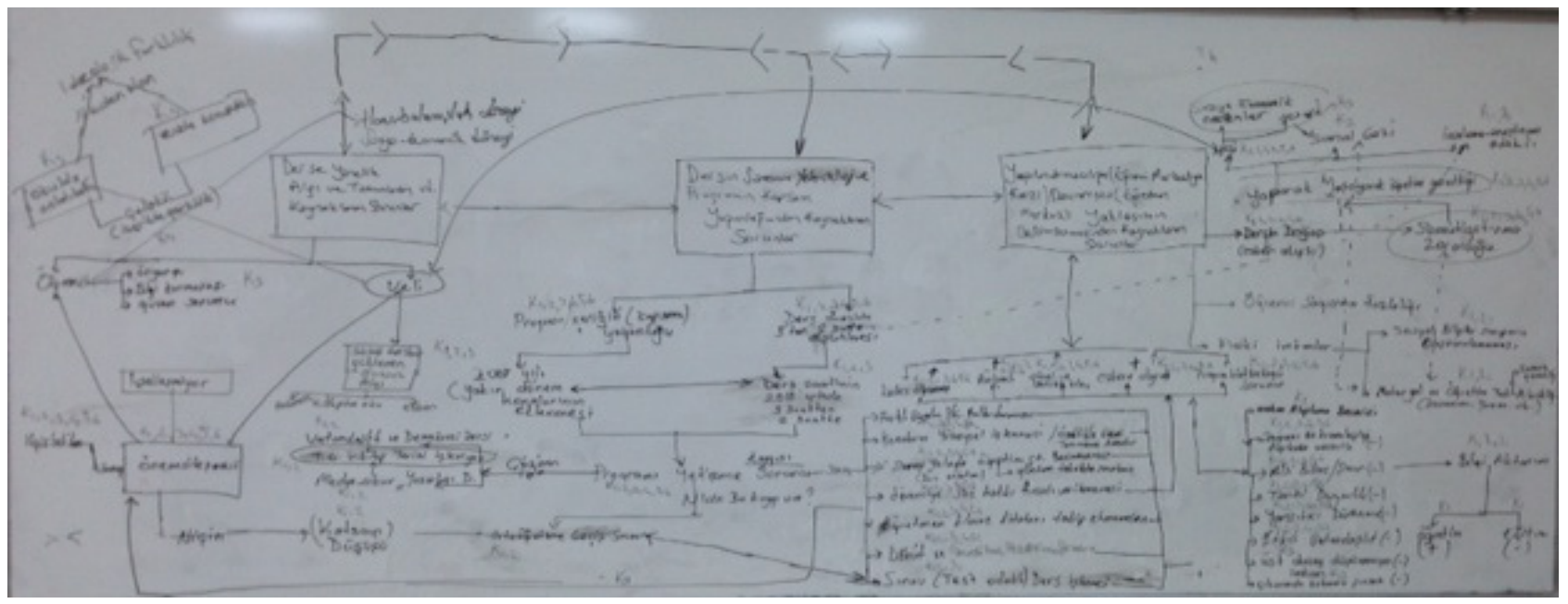

Figure 2. The Pattern Showing the Relation between themes and findings obtained

\subsubsection{Credibility, Transferability, Consistency and Confirmability for Qualitative Dimension}

\subsubsection{Credibility}

Validity is one of strengths of qualitative research and it is based on the determination of whether findings are accurate in the view of the reader, the participant and the researcher [22]. To increase the validity of the study, the studies by Adalar [2], Bingöl [8], Camkıran [15], Delen [24], MEB [58] were examined, conceptual framework with regard to the issue was developed and the interview form was developed. The interviews with the study group were transcribed and the transcriptions were examined by the participants for the verification of their accuracy.

\subsubsection{Transferability}

All the interviews with the study group were recorded with a voice recorder device. All the data obtained in the research process were assessed and coded one by one by the researchers and another faculty who has good command of qualitative research methods and overall agreement among all coders was achieved. Each process in the study is presented to the readers in details. Detailed descriptions are used in the reporting process so that they can visualize all components of the process. To this end, researchers are of the opinion that descriptive data can be transferred to the study groups in similar contexts. According to the researchers, results obtained in this study will be understood in the same or similar way. In this context, the findings of the study were summarized with a plain and clear-cut manner so that readers can visualize the research process and research medium.

\subsubsection{Consistency}

To increase the consistency of the study, all of the qualitative data were presented to the readers without any generalization. All the data obtained in the research process were evaluated and coded one by one by the researchers and another faculty who has good command of qualitative research methods and overall agreement among all coders was achieved. For the reliability calculation of all coding in the study, reliability formula proposed by Miles and Huberman [60] were used [Reliability $=$ Agreement $/$ (Agreement +Disagreement)]. In the coding, over $80 \%$ agreement was achieved for each question.

\subsubsection{Confirmability}

To ensure confirmability of the study, raw data, coding and patterns obtained in the process are stored by the researchers so that interested people can examine them.

\subsection{Quantitative Phase}

Data collected in the qualitative phase, which is the first stage of the study, form a basis for the quantitative dimension. In this context, instead of comparing qualitative and quantitative data, answer for the following question was sought: "Can qualitative themes be generalized to the universe?"

\subsubsection{Quantitative Study Group}

To determine the study group of the research two phase clustering method was used. Initially, the aim was to form a sample composed of Social studies teachers from all cities in Turkey. To this end, each of the seven geographical regions was considered as a cluster. Cities from each cluster were chosen randomly. Later on, equal numbers of teachers from each city was included in the sample by considering answer rates. With this aim in mind, the study group was composed of 1090 Social studies teachers from 28 cities who had at least work experience of more than five years. In line with the aim of the study, Social studies teachers from 7 geography regions were interviewed face to face. All social studies teachers who volunteered to fill in the quantitative data collection were included in the study. $31,2 \%$ of the teachers in the study group was female, $68,8 \%$ was male. The cities where the teachers in study group work are presented in Table 2. 
Table 2. Information with Regard to the Study Group

\begin{tabular}{|c|c|c|c|c|c|}
\hline \multicolumn{2}{|l|}{ Region } & $\mathbf{n}$ & $\%$ & Total & $\%$ in the total \\
\hline \multirow{4}{*}{ Marmara Region } & İstanbul & 40 & 3,5 & \multirow{4}{*}{156} & \multirow{4}{*}{14} \\
\hline & Bursa & 40 & 3,5 & & \\
\hline & Edirne & 38 & 3,5 & & \\
\hline & Tekirdağ & 38 & 3,5 & & \\
\hline \multirow{4}{*}{ Central Anatolia Region } & Ankara & 40 & 3,5 & \multirow{4}{*}{156} & \multirow{4}{*}{14} \\
\hline & Sivas & 39 & 3,5 & & \\
\hline & Konya & 39 & 3,5 & & \\
\hline & Kayseri & 38 & 3,5 & & \\
\hline \multirow{4}{*}{ Eastern Anatolia Region } & Van & 40 & 3,5 & \multirow{4}{*}{156} & \multirow{4}{*}{14} \\
\hline & Ağrı & 39 & 3,5 & & \\
\hline & Elazığ & 38 & 3,5 & & \\
\hline & Malatya & 39 & 3,5 & & \\
\hline \multirow{4}{*}{ Southeastern Anatolia Region } & Diyabakır & 40 & 3,5 & \multirow{4}{*}{156} & \multirow{4}{*}{14} \\
\hline & Şanlıurfa & 40 & 3,5 & & \\
\hline & Batman & 38 & 3,5 & & \\
\hline & Mardin & 38 & 3,5 & & \\
\hline \multirow{4}{*}{ Aegean Region } & İzmir & 39 & 3,5 & \multirow{4}{*}{154} & \multirow{4}{*}{13} \\
\hline & Muğla & 39 & 3,5 & & \\
\hline & Aydın & 38 & 3,5 & & \\
\hline & Denizli & 38 & 3,5 & & \\
\hline \multirow{4}{*}{ Mediterranean Region } & Antalya & 40 & 3,5 & \multirow{4}{*}{156} & \multirow{4}{*}{14} \\
\hline & Mersin & 40 & 3,5 & & \\
\hline & Adana & 38 & 3,5 & & \\
\hline & Hatay & 38 & 3,5 & & \\
\hline \multirow{4}{*}{ Black Sea Region } & Samsun & 40 & 3,5 & \multirow{4}{*}{156} & \multirow{4}{*}{14} \\
\hline & Ordu & 40 & 3,5 & & \\
\hline & Giresun & 38 & 3,5 & & \\
\hline & Trabzon & 38 & 3,5 & & \\
\hline Total & 28 cities & 1090 & $100 \%$ & 1090 & $100 \%$ \\
\hline
\end{tabular}

\subsubsection{Development of a Scale for the Problems Social} Studies Teachers Face in TRHRK Course (HRKC-PS)

\subsubsection{Development of an Item Pool}

In the development process of the scale with regard to the problems Social studies teachers face in TRHRK course, first of all items were written using the codes obtained in the qualitative phase, descriptive quotations from the participants statements and the categories obtained as a result of content analysis and themes. Item tool was developed based on the data obtained in the qualitative process. As a result of all examinations, a 30 -item pilot item pool including 14 items related to the first theme, 7 items related to the second theme and 9 items related to the third theme was created.

In this study, the scale was graded as follows: "I totally disagree: 1", “I disagree: 2", "I partially agree /disagree: 3", "I agree: 4" and "I totally agree: 5". All the attitude items were written to express factual cases not desirable/ undesirable cases. Later on, two different faculty members, who hold $\mathrm{PhD}$ degree in Social studies Education and History Education, were asked to criticize the items in the item pool, the aim of the study, the way they are expressed and especially for their compliance with qualitative findings.

In order to determine expert views, the items were graded in three levels as "suitable", "partially suitable," and "not suitable" and experts were asked to assess them. The items for which were viewed as "not suitable" were taken out of item pool, the items which were viewed as "partially suitable" were changed according to expert views. While two items were amended according to expert feedback in terms of expression and compliance with qualitative 
findings, 3 items were removed from the item pool.

All items were examined with the help of an expert who holds $\mathrm{PhD}$ in education in terms of language, meaning and expression. After the examinations, necessary changes with regard to punctuation, spelling, language, meaning and expression were made. In this process, it was decided that there was no need to remove any item from the item pool.

After these stages, tentative item pool was assessed by a faculty member who holds $\mathrm{PhD}$ and who is experienced in scale development. Throughout the process defined above, the items were evaluated in terms of whether factual cases could be expressed and type of expression, compliance with the aim of the study and qualitative data and content validity. As the faculty member stated that 2 items did not exactly match, these items were removed from the item pool.

As a result, 3 items were omitted from the item pool in line with feedback from two lecturers who are expert in History and Social studies Education, and 2 items were removed in line with feedback from two lecturers who are expert in Assessment and Evaluation. Thus 5 items were eliminated from the tentative item pool which had 30 items before the pilot application.

\subsubsection{Pilot Application Process}

Before pilot application, the tentative item pool had 25 items. The draft scale, whose items were ordered randomly, was piloted with 132 Social studies teachers who work in Sivas and not included in the qualitative study group. 132 teachers who took part in the pilot application were not included in the study group. The pilot application included five times more teachers than the number of items in the tentative pool. As a result of pilot application, draft data collection tool filled in by 132 Social studies teachers were transferred on PASW 18 software, basic descriptive and inferential statistical analyses were made on the items. It was determined that two items were left blank more than $10 \%$ of the teachers. Therefore, these items were removed from the pool. When the researchers were applying tentative item pool in the pilot application process, they followed the process as non-participant observers. After expert views and pilot application process, 23-item draft scale was administrated to the quantitative sample of the study. As stated by Bulling [14], and Creswell and PabloClark [21], these data were used both in EFA and CFA analyses in the scale development process and as a basis for quantitative findings.

\subsubsection{Findings with Regard to Construct Validity}

Before explanatory factor analysis, item-test correlations of 23-item tentative scale were calculated and it was seen that item-test correlation for all item-test correlation was higher than 0.40. In explanatory factor analysis, first of all Kaiser-Meyer-Olkin (KMO) test was applied to determine the suitability of sample size for constructing factors. As a result of analysis KMO value was found to be 0.710 , which is higher than 0.60 limit value. In line with this finding, it was concluded that sample size is "adequate" for factor analysis [12, 69]. Besides, when Bartlett sphericity test result were examined, it was determined that chi-square value was significant $(\mathrm{X} 2(253)=12297.919 ; \mathrm{p}<.01)$. Based on these results, it was accepted that data can create factors $[17,44,69]$.

\subsubsection{Exploratory Factor Analysis of HRKC-PS}

In order to determine the factor construct of HRKC-PS, principal component analysis, and varimax technique, which is one of the vertical rotation methods were chosen by considering openness and significance issues [12,83]. However, as a result of the first factor analysis, promax technique, which is one of the skewed rotation techniques, was used because the correlation between factors was higher than 0.30 and factors were developed dependent on a qualitative pattern and were directly related to each other.

In the exploratory factor analysis, which was repeated a few times with the technique stated, 0.40 was determined as the lower limit for factor load value, and three items which were lower than this value were eliminated (item 4, 5 and 12). When factor load values in the scale were examined, it was determined that 1 item (item 10) loaded high value on more than one factor and the difference between the factor load values was lower than 0.10 . Therefore, these items were regarded as overlapping items and removed from the scale. After each factor analysis performed observing the items designed according to the themes in tentative item pool and the logical and content related reasons the relation between the item and content, meaning and most importantly theme presented as qualitative findings, incompatible items were eliminated. As a result, in line with logical reasons mentioned above and the study design and procedures, two items (item 16 and 19) were removed from the scale. In this process, the procedures mentioned in mixed method studies by Balc1 [4], Brownlow [12], Hutcheson and Sofroniou [44], Creswell [20], Fabrigar and Wegener [31] and particularly Bulling [14], were followed.

\subsubsection{Exploratory Tool Design in the Study}

Factor analysis was once again applied to the scale which decreased down to 17 items after 6 items shown to be problematic in EFA were omitted. As a result of explanatory factor analysis, as aimed based on qualitative findings there were 3 factors with eigien value larger than 1 . It was seen that the first factor contributed $19.151 \%$, the second factor contributed $17.488 \%$ and the third factor contributed $13.295 \%$ to the common variance. Total variance explained by these three factors is $49.934 \%$ and this percentage is adequate for multi factorial patterns [12, $31,44]$. Factorial design obtained as a result of EFA and factor load of the items are given in Table 3. Consequently, there are 8 items in the first dimension, 4 items in the second dimension and 5 items in the third dimension. 
Table 3. Factorial Structure of HRKC-PS as a result of EFA

\begin{tabular}{|c|c|c|c|c|c|}
\hline $\begin{array}{c}\text { Dimension related to inadequacy of course } \\
\text { time and intensity of course content }\end{array}$ & \multicolumn{2}{|c|}{$\begin{array}{c}\text { Dimension Related to the adoption of } \\
\text { Behaviorism instead of Constructivism }\end{array}$} & $\begin{array}{c}\text { Dimension related to perception and attitude } \\
\text { towards the course and other factors }\end{array}$ \\
\hline Item No & Factor Load & Item No & Factor Load & Item no & Factor Load \\
\hline 2 & 0.784 & 22 & 0.809 & 21 & 0.912 \\
\hline 1 & 0.741 & 13 & 0.673 & 20 & 0.897 \\
\hline 3 & 0.702 & 14 & 0.596 & 17 & 0.760 \\
\hline 23 & 0.695 & 6 & 0.411 & & 0.606 \\
\hline 9 & 0.672 & & & & 0.525 \\
\hline 8 & 0.609 & & & & 15 \\
\hline 7 & 0.583 & & & & \\
\hline 11 & 0.560 & & & & \\
\hline
\end{tabular}

2.4.2.6. Item-total Correlations and Item Discrimination Characteristics

Item-test correlation values explaining validity coefficient for each item are given in Table 4.

Table 4. Item-test correlation values for HRKC-PS

\begin{tabular}{|c|c|c|c|c|c|c|c|c|c|c|c|c|c|c|c|c|c|}
\hline \multirow{2}{*}{ Factors } & \multicolumn{17}{|c|}{ Items } \\
\hline & 2 & 1 & 3 & 23 & 9 & 8 & 7 & 11 & 22 & 13 & 14 & 6 & 21 & 20 & 18 & 17 & 15 \\
\hline $\begin{array}{l}\text { Dimension related to } \\
\text { inadequacy of course } \\
\text { time and intensity of } \\
\text { course content }\end{array}$ & ,609 & ,632 &, 573 & ,690 & ,625 & ,625 & ,589 &, 545 & & & & & & & & & \\
\hline $\begin{array}{l}\text { Dimension Related to } \\
\text { the adoption } \\
\text { Behaviorism instead of } \\
\text { Constructivism }\end{array}$ & & & & & & & & &, 558 &, 751 & ,700 & ,618 & & & & & \\
\hline $\begin{array}{l}\text { Dimension related to } \\
\text { perception and } \\
\text { attitude towards the } \\
\text { course and other } \\
\text { factors }\end{array}$ & & & & & & & & & & & & & ,665 & ,681 &, 733 & ,616 &, 550 \\
\hline Total & ,493 & ,508 & ,502 & ,537 & ,574 & ,570 & ,491 & ,468 & ,595 & ,604 & ,505 &, 521 & ,551 & ,556 & ,718 &, 524 & ,458 \\
\hline
\end{tabular}

It is seen that the item-test correlation coefficients of items given in Table 3 range between 0.751 and 0.545 . These values indicate that three items have high level $(0.70$ $-1.00)$ and other items have medium level $(0.30-0.70)$ item test correlation [12].

There is a medium level and significant correlation $(0.405)$ between the dimensions related with inadequacy of course time and intensity of syllabus content and the dimension of the adoption of the Behaviorist Approach opposed to Constructivism. Besides, there is a low level and significant correlation $(0.260)$ between the dimensions related with inadequacy of course time and intensity of program and the dimension related to perception and attitude towards the course and other factors. And there is a low level and significant correlation $(0.234)$ between the dimension related to the Behaviorist Approach as opposed to Constructivism and the dimension related to perception and attitude towards the course and other factors.
Independent sample t-test was used to calculate item discrimination power of the items on the scale. To this end, total scores obtained from the scale were ordered in descending order and the upper and lower $27 \%$ groups were determined. Independent t-test values were calculated based on the scores of the both groups. As a result of analysis, it was concluded that there is a significant difference between the upper and lower groups for each item on the scale $(p<.01)$. This significant finding indicates that the items on the scale have desired level of discriminative characteristic [12].

\subsubsection{Confirmatory Factor Analysis (CFA)}

To assess three factorial structure of HRKC-PS, confirmatory factor analysis (CFA) was performed. Findings obtained as a result of confirmatory factor analysis are given in Table 5 and in Figure 3. 
Table 5. CFA results of HRKC-PS

\begin{tabular}{|c|c|}
\hline Fit -Criteria & Values of HRKC-PS \\
\hline $\mathrm{X}^{2}$ & 116 \\
\hline $\mathrm{Sd}$ & $351.23(\mathrm{P}<0.01)$ \\
\hline $\mathrm{X}^{2} / \mathrm{sd}$ & 3.02 \\
\hline $\mathrm{p}-$ Value & 0.001 \\
\hline NFI (Normed Fit Index) & 0.95 \\
\hline NNFI (Non-Normed Fit Index) & 0.91 \\
\hline RMR (Root Mean Square Residual) & 0.092 \\
\hline SRMR (Standardized Root Mean Square Residual) & 0.099 \\
\hline GFI (Goodness of Fit Index) & 0.95 \\
\hline AGFI (Adjusted Goodness of Fit Index) & 0.87 \\
\hline CFI (Comparative Fit Index) & 0.96 \\
\hline RFI (Relative Fit Index) & 0.91 \\
\hline IFI (Incremental Fit Index) & 0.96 \\
\hline PNFI (Parsimony Normed Fit Index) & 0.84 \\
\hline
\end{tabular}

It is seen in CFA that HRKC-PS has acceptable fit level as the rate of $\mathrm{X}^{2}$ to freedom degree is a little above 3 (3,02), and has good fit because GFI is 0.95 , AGFI is 0.87 and CFI is 0.96 The other fit values are within acceptable limits [5, 11, 79]. These values indicate that the scale is compatible with real data. As it was understood that all goodness of fit values are within acceptable limits, it was concluded that there factorial HRKC-PS is usable and valid model.

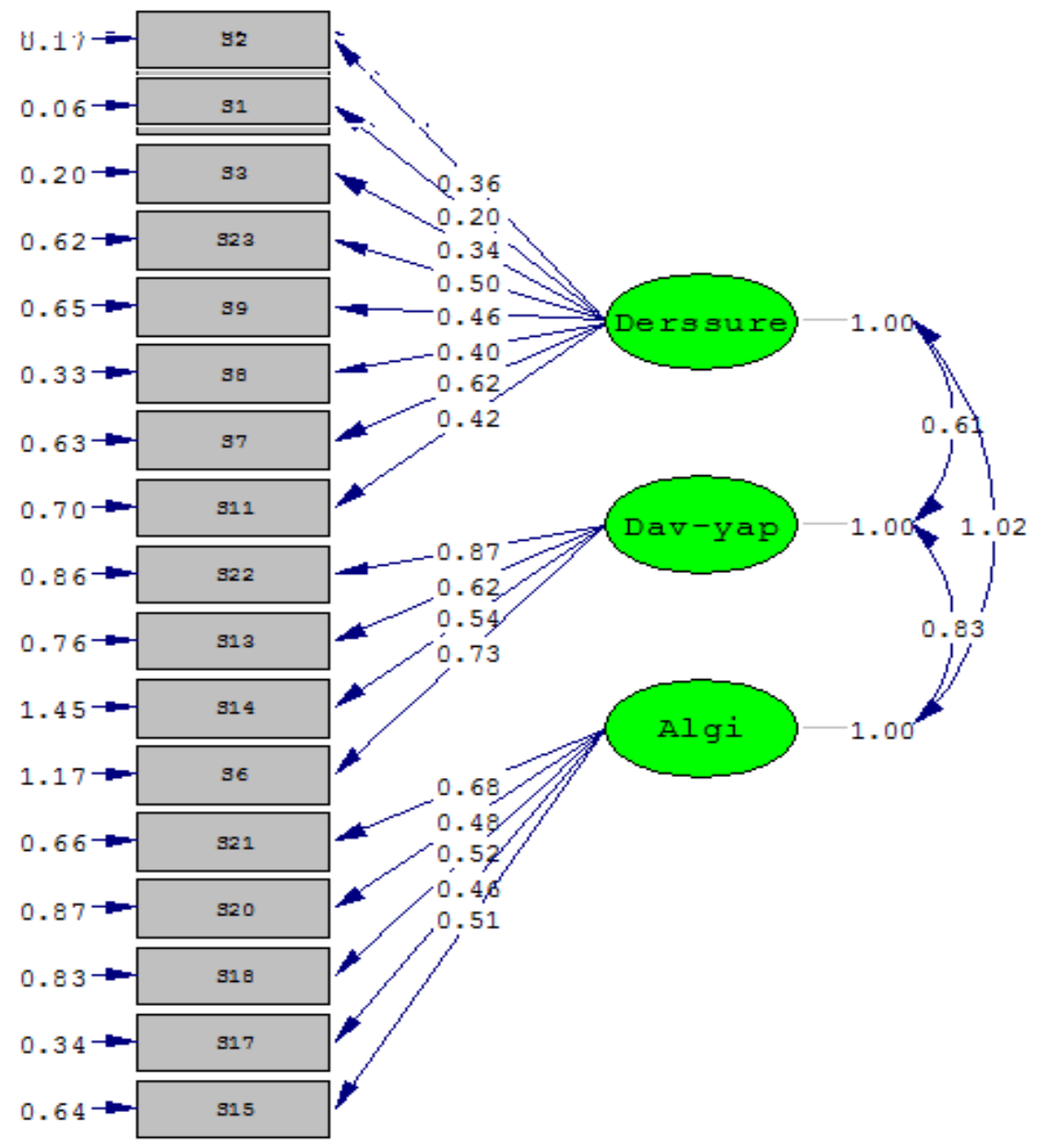

Figure 3. Confirmatory Factor Analysis of HRKC-PS (Path Diagram) 


\subsubsection{Findings with Regard to Internal Consistency}

Cronbach Alpha reliability analysis was performed to determine reliability coefficient of the scores obtained from HRKC-PS. The Cronbach Alpha coefficient was calculated as 0.853 . The Cronbach Alpha reliability coefficient was 0.769 for the dimension of inadequacy of course time and intensity of syllabus content, which is one of the sub-factors. The Cronbach Alpha reliability coefficient was 0.675 for the dimension related to the adaptation of the Behaviorist Approach as opposed to Constructivism and 0.660 for the dimension related to perception and attitude towards the course and other factors. These results indicate that sub-scales are reliable [12]. All these results provided above indicate that the scale developed based on qualitative data is a valid data collection tool with adequate psychometric characteristics.

\subsubsection{Validity in Mixed Research}

In mixed method research, researchers who use exploratory sequential mixed method design are to check the validity of quantitative data together with qualitative data validity. Special concerns with regard to validity emerge. Besides, when using this design the researcher who makes the research proposal is to participate in the study. The concern in this issue is to use appropriate steps to develop a measurement tool with good psychometric characteristics [21].

In line with these issues, this study attempted to develop a measurement tool with good psychometrics characteristics. In this process, the steps mentioned above were followed and the advantages of the richness of qualitative data were used when developing the measurement tool. Finally, to prevent the repetition of the responds, the sample in the qualitative dimension was not included in quantitative dimension. For qualitative dimension, credibility, transmissibility and confirmability were presented to readers under separate headings and this process was carried out according to qualitative research procedures. Validity and reliability for the quantitative dimension was calculated in detail and step by step.

\section{Findings}

\subsection{Qualitative Findings}

As a result of analysis of the interviews made in the study, there themes were found with regard to the problems Social Studies teachers face in TRHRK course. These themes are:

1. The problems stemming from the inadequacy of the course time and the intensity of the syllabus content.

2. The problems stemming from the adoption of Behaviorist Approach as opposed to Constructivism.

3. The problems stemming from perception and attitude towards the course and other factors.

\subsubsection{The Inadequacy of the Course Time and Intensity of Program's Content}

The fundamental finding of the study is that participants experience that it is not possible to cover the content (attainments, activities) of TRHRK course mentioned in the educational program in the allocated course hours. Participants stated that in line with constructivist approach the course hour was increased from 2 to 3 by the Board of education and discipline in 2008 and this continued until 2010. However, the unit titled as "Turkey in Recent Period: The Second World War and After it" was added in the syllabus and the number of weekly course hours was decreased from three hours to two hours. As a result of these changes, the problem of not being able to cover the content of the syllabus emerged, which caused teachers to feel the anxiety of finishing the program. With regard to this anxiety, P5 stated that "I cannot cover so many subjects. I am not a superman, I have supernatural powers" and wanted to emphasize that it was not possible to cover the content of the program according to the principles of the constructivist approach.

The scope of the syllabus and the inadequacy of the weekly course hour caused teachers to have the anxiety of covering the syllabus in time. It was determined that the source of this anxiety was the desire to cover the content of TRHRK questions asked in the TRHRK course common exam administrated by the Ministry of National Education. P6 stated that the time period allocated to cover such an intensive program was one of the fundamental problems experienced in TRHRK course and perceived this problem as the source of other problems. P6 used the simile of "race horse" to envisage how much effort they showed and their dissatisfaction. Examples based on experience were used to emphasize that this opinion was dominant among all participants. The anxiety to finish the course syllabus caused the participants to adopt teaching via expository teaching strategy, not to use different methods and techniques other than narration and question answer technique, to teach the subjects superficially, not to be able to allocate enough time for the subjects, which engrain in the consciousness of citizenship and acculturation. They are the important elements of Social Studies education, which is supposed to engrain in national consciousness and historical sensitiveness. Besides, lack of time causes them to go astray from the instruction in teacher's guidebook, and not to be able to integrate the elements of feedback, motivation and consolidation in their lessons. P123456 made self-assessment and they stated that they taught the lesson using the expository teaching method and stated that the basic reason for this was the anxiety of covering the syllabus in time.

The anxiety of covering the syllabus caused the participant teachers not to give enough voice to students, which exactly conflicts with the structure and philosophy of the syllabus. It emphasizes its relation to the second theme of the study, using behaviorist approach instead of constructivism. While 
P6 stated that the attainments in the program could not be covered and if the students were given voice in the lessons, it was seen that almost all of the participants were of the same opinion. The anxiety of finishing the syllabus stemming from the limited time allocated for the course, caused the participants no to be able follow the teacher's guide book which was designed according to the constructivist approach. All of the participants stated that they did not use the guidebook and that if they used it, the syllabus would not be covered if they used the guidebook. With regard to this issue, $\mathrm{P} 2$, stated that "if I were to follow the steps mentioned in the guidebook, I would not be able to finish even half the syllabus. Let alone the questions that I am suggested to ask to the students, I would not be able to cover the topics even if I just taught the topics in the book". It was also clearly stated by the participants that when the inadequacy of course time and the desire of the students to prepare for Transition to Secondary Education Exam were combined, they studied the topics superficially to meet the requirements of a multiple choice exam and thus digressed from the assessment tools used in the constructivist approach. Besides, they attached importance to the attainments by categorizing them according to the possibility of "their being asked or not in the exam".

They stated that they were not able to spare enough time for many topics including the Çanakkale Victory, Historical Congresses, Period of National Struggle, which were believed to engrain in national consciousness and historical sensitiveness. The participants are clearly of the opinion that the problems stemming from the anxiety of covering the syllabus blocked the way to long-lasting and meaningful learning and caused lessons to be based on rote learning, exam focused, not having topical integrity.

In parallel with this and based on the problems mentioned above, the participants stated they that they could not provide opportunities for high level thinking and for making inferences and had to teach lessons which are deprived of the quality to help learners acquire the skills to perceive place, time and chronology and related this issue with the first theme. Besides, it was determined that they digressed from the aims of THRK course like effective citizenship, national consciousness and historical sensitiveness, lost their educational mission and took over the mission of information transmission, in their own words. P6 summarizes the issue mentioned above by saying "We continuously think about the topics about which questions can be asked on the exam, the things to be done. I mean we always think about transmitting knowledge. How can we help children to make permanent behavioral change? We do not ponder on things like that."

From the statements of P123456, it was found that they could finish the topics of TRHRK course with makeup lessons in some elective courses like Media Literacy course and Citizenship and Democracy Education course. When inadequacy of course time and the desires of the students to prepare for transition to secondary education exam (TEOG) are combined, all the participant social Studies teachers stated they used the courses which are not included in TEOG exam as make up courses.

\subsubsection{The problem Caused by Teachers' Adoption of the Behaviorist Approach as Opposed to Constructivism}

The basic factors in the collection of findings obtained under this theme are the findings in the first theme. In other words, these two themes are closely related to each other. The fact that inadequacy of course time determined in the scope of the first theme causes the anxiety of finishing the syllabus. This anxiety causes the adoption of the behaviorist approach, the use of direct narration method instead of different methods, teaching the topics superficially, not giving enough voice to students, digression from the teacher's guidebook, formation of rote learning and information transmission focused learning environment instead of meaningful, up-to-date and realistic course. These factors cause a syllabus designed according to the constructivist approach to be taught according to the behaviorist approach. The abstract dimension of TRHRK course by its nature makes it far from learning by experience compared to other courses; therefore, the participants think that the course should be taught with a teacher-centered approach, which is one of the biggest problems experienced.

The basic factors that cause the adoption of Behaviorist approach instead of constructivism can be categorized as follows: the physical inadequacy of the education environment, high number of students, teacher's perception with regard to the nature of the course, socio-economic factors. In the study, lack of single classes for Social Studies because of inadequate physical conditions, inadequacy of materials and instructional technology, lack of software and other materials were determined as other factors which cause the inability to apply constructivism.

When existing difficulties by the nature of the course are considered, it is seen that most of the participants stated the obligation of concretizing topics and attainments as a difficulty. It was concluded that study visits are to be organized so that students can learn by doing; however, there is no opportunity for such activities because of financial problems, parents' attitudes, and safety problems, official procedures, which can be expressed as socio-economic and socio-cultural reasons. This case was expressed by $\mathrm{P} 4$ as follows: "Actually the Çanakkale Victory is to be taught in the place where the war was fought. We cannot afford it. We live in the country. Yes, we do not live in a village, we live in a county but we cannot make such study trips because the socio-economic levels of the students vary." P6 states that "To make a historical trip, environment and economy are both important. Even if I plan to make a visit trip to historical places in Sivas, so many students do not join the trip, some parents do not allow their children to join the trip, some simply cannot afford and sometimes bureaucratic problems...." As study trips and in school activities cannot be made because of the reasons mentioned above, teachers to 
turn to virtual trips; however, it was found that because of the inadequacy of equipments and infrastructure and the inadequate teacher knowledge and skill, research and study focused education environment in which learners learn by doing cannot be provided, which is one of the factors that make the application the constructivist approach in TRHRK courses impossible.

\subsubsection{Problems Caused by Perception and Attitude towards} the Course and Other Factors

Under the theme called the problems caused by the perception and attitude towards the course and other factors in general the problems related to students and parents were found as reasons for the problems Social Studies teachers experience in TRHRK. In particular, the findings from the first two themes indicated that students did not internalize the course, and they did not care about the course by saying "After all it is written in the book." In other words, it was determined that all the participants thought that the reasons mentioned in the first and second theme caused the students to trivialize the course in their minds. The fact that the percentage of the questions from TRHRK course in central exams administrated for transition to secondary school is relatively low when compared to those of Mathematics, Science and Technology course was also expressed by the participants as another factor that trivialize the course in the view of the students. According to the participants, students' viewing the lesson as not important takes students away from the course and draw them to indifference.

In the study, the difference between students' readiness level and socio-economic level was stated by the participants as another problem faced in TRHRK course. Another factor causing the problems experienced in TRHRK course were determined to be problems caused by parents or factors outside the school. It is claimed that versions of historical events talked about at home or in close environment are different from those taught at school because of ideological differences. This causes the students to have a conflicting mental scheme in their minds with regard to history. It was claimed by the participants that this conflict led to prejudice or negative attitudes of learners towards the course, to informational convergence and to problem of trust. P3 stated the problem by saying the following sentences: "The parents of the students have some negative judgments about the History of Revolution. These are spoken in the family and students who hear such things make comments about these topics. We are having problems with regard to this issue. The attitudes of families and what we teach are different, students have some problems. This is the most common problem I have with regard to this issue ..."

\subsection{Quantitative Findings}

\subsubsection{Inferential Statistics}

There is not a significant difference between the participants in the quantitative study group and the first dimension ( $\mathrm{t} 51=-1.45, \mathrm{p}=.227>.05)$; the second dimension $(\mathrm{t} 51=-1.61, \mathrm{p}=.775>.05)$ and the third dimension $(\mathrm{t} 51=-1.96$, $\mathrm{p}=.163>.05)$ in terms of gender. Besides, there is not a significant difference between the service lengths of the participants and the first dimension $(\mathrm{F}=1.035, \mathrm{p}=.311>$ 0.05); the second dimension ( $\mathrm{F}=9,16, \mathrm{p}=, 848>.05)$ and the third dimension $(\mathrm{F}=1,17, \mathrm{p}=, 311>.05)$. No significant difference between the participants in the first dimension ( $\mathrm{F}$ $=1,37, \mathrm{p}=, 242>.05))$ and the second dimension $(\mathrm{F}=1,19, \mathrm{p}$ $=, 310>.05$ ) was found in terms of the region where the participants work. However, it was found that there was a significant difference between the participants in the third dimension $(\mathrm{F}=5,09, \mathrm{p}=, 002<.05))$ in terms of the region where the participants work. For example, the participants working in the Black Sea $(\bar{x}=4,78)$, Eastern Anatolia $(\bar{x}=4,71)$ and Southeastern Anatolia Region $(\bar{x}=3,68)$ experienced more problems with regard to "perception and attitude towards the course and other factors" compared to the participants working in other regions.

\subsubsection{Descriptive Statistics}

\subsubsection{The Quantitative Findings with Regard to Inadequacy of the Course Time and the Intensity of the Syllabus}

The quantitative findings with regard to inadequacy of the course time and the intensity of the syllabus are given in Table 6. 
590 The Obstacles for the Teaching of 8th Grade TR History of Revolution and Kemalism Course According to the Constructivist Approach (An Example of Exploratory Sequential Mixed Method Design)

Table 6. The quantitative findings with regard to inadequacy of the course time and the intensity of the syllabus

\begin{tabular}{|c|c|c|c|c|c|c|c|c|c|c|c|c|c|}
\hline \multirow[t]{2}{*}{$\begin{array}{l}\text { The dimension related with regard } \\
\text { to inadequacy of the course time and } \\
\text { the intensity of the syllabus }\end{array}$} & \multirow[b]{2}{*}{$\mathbf{n}$} & \multirow[b]{2}{*}{$\bar{x}$} & \multirow[b]{2}{*}{ Ss } & \multicolumn{2}{|c|}{ I totally agree } & \multicolumn{2}{|c|}{ I agree } & \multicolumn{2}{|c|}{$\begin{array}{c}\text { I partially } \\
\text { agree/disagree }\end{array}$} & \multicolumn{2}{|c|}{$\begin{array}{c}\text { I } \\
\text { disagree }\end{array}$} & \multicolumn{2}{|c|}{$\begin{array}{l}\text { I totally } \\
\text { disagree }\end{array}$} \\
\hline & & & & $\mathbf{n}$ & $\%$ & $\mathbf{n}$ & $\%$ & $\mathbf{n}$ & $\%$ & $\mathbf{n}$ & $\%$ & $\mathbf{n}$ & $\%$ \\
\hline $\begin{array}{l}\text { 2- When the weekly hour of the } \\
\text { TRHRK course was decreased from } \\
\text { three hours to two hours in } 2010 \text {, the } \\
\text { problem of finishing the syllabus } \\
\text { emerged, in other words the problem in } \\
\text { the acquisition of the attainments } \\
\text { emerged. }\end{array}$ & 1090 & 4,8807 & ,32425 & 960 & 88,1 & 130 & 11,9 & 0 & 0 & 0 & 0 & 0 & 0 \\
\hline $\begin{array}{l}\text { 1- It is not possible to finish the content } \\
\text { ( attainments, activities) of TRHRK } \\
\text { syllabus within the course hour. }\end{array}$ & 1090 & 4,8349 & ,55071 & 960 & 88,1 & 110 & 10,1 & 0 & 0 & 10 &, 9 & 10 & ,9 \\
\hline $\begin{array}{l}\text { 3- It is not possible to teach TRHRK } \\
\text { course according to the principles of } \\
\text { the constructivist approach. }\end{array}$ & 1090 & 4,7064 & ,56371 & 830 & 76,1 & 200 & 18,3 & 60 & 5,5 & 0 & 0 & 0 & 0 \\
\hline $\begin{array}{l}\text { 23- In TRHRK course, Social Studies } \\
\text { teachers can finish the topics via make } \\
\text { up lessons in some elective courses like } \\
\text { Media Literacy and Citizenship and } \\
\text { Democracy Education }\end{array}$ & 1090 & 4,5872 & ,95068 & 860 & 78,9 & 120 & 11,0 & 30 & 2,8 & 50 & 4,6 & 30 & 2,8 \\
\hline $\begin{array}{l}\text { 9- In TRHRK course, the inadequacy } \\
\text { of the course time causes Social } \\
\text { Studies teachers to digress from the } \\
\text { instructions in the guide book and not } \\
\text { to follow the guide book. }\end{array}$ & 1090 & 4,3394 & 1,00705 & 640 & 58,7 & 300 & 27,5 & 70 & 6,4 & 40 & 3,7 & 40 & 3,7 \\
\hline $\begin{array}{l}\text { 8- In TRHRK course Social Studies } \\
\text { cannot allocate enough time for topics } \\
\text { which are regarded as important } \\
\text { because they engrain in citizenship } \\
\text { consciousness and acculturation, which } \\
\text { are seen as the fundamental principles } \\
\text { of Social studies education. }\end{array}$ & 1090 & 4,5229 & ,69889 & 680 & 62,4 & 320 & 29,4 & 70 & 6,4 & 20 & 1,8 & 0 & 0 \\
\hline $\begin{array}{l}\text { 7- In TRHRK course, the inadequacy } \\
\text { of the course time cause the topics to be } \\
\text { taught superficially. }\end{array}$ & 1090 & 4,3853 & ,92817 & 660 & 60,6 & 290 & 26,6 & 40 & 3,7 & 100 & 9,2 & 0 & 0 \\
\hline $\begin{array}{l}\text { 11- In TRHRK course Social studies } \\
\text { teachers cannot give students enough } \\
\text { voice in the lessons because of the } \\
\text { anxiety of finishing the syllabus. }\end{array}$ & 1090 & 4,3119 & ,93594 & 590 & 54,1 & 350 & 32,1 & 60 & 5,5 & 80 & 7,3 & 10 & ,9 \\
\hline
\end{tabular}

While $88,1 \%$ of the participants in the study group completely agree that decrease in the weekly hours of TRHRK course from three hours to two hours in 2010 has caused the problem of finishing the syllabus, in other words acquiring the attainments, $11,9 \%$ stated that they agreed with that. This item developed based on qualitative findings was answered positively by all participants. The qualitative finding that as a result of decrease in TRHRK course's weekly hour in 2010, the problem of finishing the syllabus, in other words the problem of acquisition of attainments, emerged was quantitatively supported by the participants at a high level $(\bar{x}=4.8807) .88,1 \%$ of the participants in the study completely agreed with the conclusion that "It is not possible to finish the content of the TRHRK syllabus", $10,1 \%$ answered that they agreed. This item developed based on qualitative findings was answered positively by $98,2 \%$ of the participants. The rate of those who did not agree with this statement was rather low $1,8 \%$.

$76,1 \%$ of the participants in the study completely agreed with the conclusion that it was not possible to finish the syllabus of TRHRK course according to the principles of the constructivist approach within time allocated for the course, and the percentage of those who stated that they agreed was $18,3 \% .94,4 \%$ of the participants stated that they agreed with this item developed based on qualitative findings. The rate of those who agreed partially was $5,5 \%$. The qualitative finding that it is not possible to finish the syllabus of the TRHRK course within course time allocated was highly supported by the participants in quantitative phase $(\bar{x}=4.7064)$.

While $78,9 \%$ of the participants in the study completely agreed with the finding that "In TRHRK course, Social studies teachers can finish the topics via make up lessons in some elective courses like Media Literacy, Citizenship and Democracy Education", 11,0\% stated that they agreed. This data collected from the participants of qualitative part of the study is clearly supported by $89,9 \%$ of the participants in the quantitative part. 
While $62,4 \%$ of the participants completely agreed with the qualitative finding that "In TRHRK course Social studies cannot allocate enough time for topics which are regarded as important because they engrain in citizenship consciousness and acculturation, which are seen as the fundamental principles of Social studies education.", 29,4\% supported this finding by stating that they agreed. $91,8 \%$ of the participants in the quantitative part stated positive opinion and agreed with the finding obtained in the qualitative part.

\subsubsection{Quantitative Findings with Regard to the Adoption} of Behaviorist Approach instead of the Constructivist Approach

While $71,6 \%$ of the participants totally agree with the qualitative finding that "In TRHRK course, because of the inadequacy of course time, Social Studies teachers have to use the behaviorist methods and techniques instead of the constructivism. $21,1 \%$ stated that they agreed. While $92,7 \%$ of the participants stated positive opinion and that they agreed with this qualitative finding. While $45,0 \%$ of the participants stated that they totally agreed with the statement that "In TRHRK course, the problems caused by the inadequacy of physical conditions in the education environment is an important factor that prevents Social studies teachers to reach the attainments of the course", the percentage of those who stated that they agreed is $28,4 \%$. $73,4 \%$ of the participants in the quantitative study supported qualitative finding. The rate of those who agreed partially is $7,3 \%$. The rate of those who stated opposing view is $19,2 \%$. While $64,2 \%$ of the participants in the study completely agreed with the finding that "in TRHRK course, the anxiety to finish the syllabus cause teachers to adopt expository teaching method and not to be able to use different method and techniques other than narration and question- answer technique", $26,6 \%$ agreed with this statement. $91.8 \%$ of the participants in the quantitative part stated positive opinion and agreed with the finding obtained in the qualitative part.

Table 7. Quantitative Findings with Regard to the Adoption of Behaviorist Approach instead of the Constructivist Approach

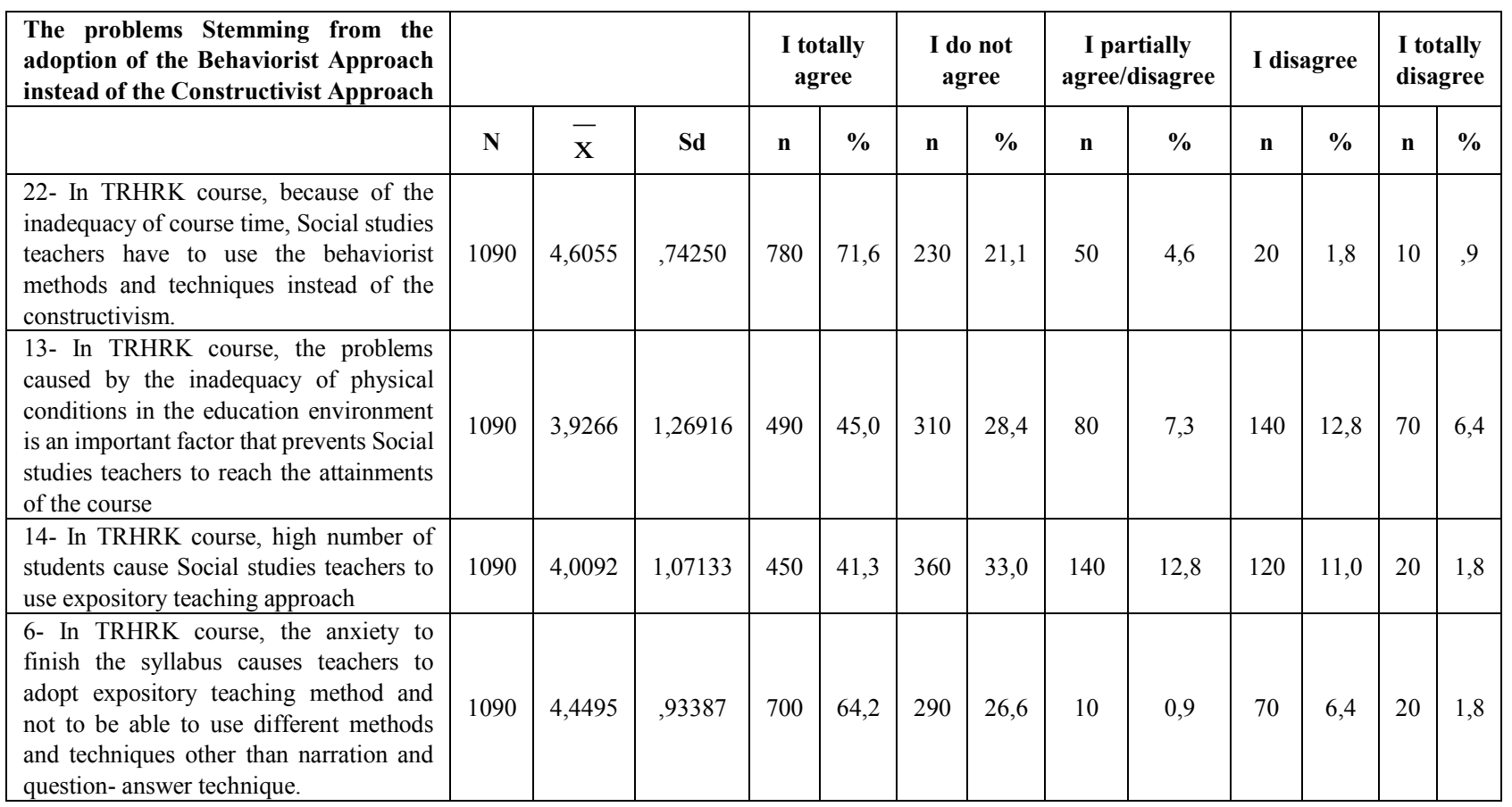


Table 8. Quantitative Findings with regard to perception and attitude towards the course and other factors

\begin{tabular}{|c|c|c|c|c|c|c|c|c|c|c|c|c|c|}
\hline \multirow[t]{2}{*}{$\begin{array}{l}\text { The problems caused by perception and } \\
\text { attitude towards the course and other } \\
\text { factors }\end{array}$} & \multirow[b]{2}{*}{$\mathbf{n}$} & \multirow[b]{2}{*}{$\bar{x}$} & \multirow[b]{2}{*}{ Ss } & \multicolumn{2}{|c|}{$\begin{array}{c}\text { I totally } \\
\text { agree }\end{array}$} & \multicolumn{2}{|c|}{$\begin{array}{l}\text { I do not } \\
\text { agree }\end{array}$} & \multicolumn{2}{|c|}{$\begin{array}{l}\text { I partially } \\
\text { agree/ } \\
\text { disagree } \\
\end{array}$} & \multicolumn{2}{|c|}{ I disagree } & \multicolumn{2}{|c|}{$\begin{array}{l}\text { I totally } \\
\text { disagree }\end{array}$} \\
\hline & & & & $\mathbf{n}$ & $\%$ & $\mathbf{n}$ & $\%$ & $\mathrm{n}$ & $\%$ & $\mathbf{n}$ & $\%$ & $\mathbf{n}$ & $\%$ \\
\hline $\begin{array}{l}\text { 21- Difference between historical topics } \\
\text { told at home and taught at school leads to } \\
\text { informational convergence and trust } \\
\text { problem for the students. }\end{array}$ & 1090 & 4,0275 & 1,04498 & 460 & 42,2 & 350 & 32,1 & 130 & 11,9 & 150 & 13,8 & 0 & 0 \\
\hline $\begin{array}{l}20 \text { - The claim that because of ideological } \\
\text { reasons there are differences between the } \\
\text { versions of the historical events talked } \\
\text { about at home or immediate environment } \\
\text { and those taught at school is one of the } \\
\text { problems social studies teachers face. }\end{array}$ & 1090 & 4,1193 & 1,04732 & 520 & 47,7 & 320 & 29,4 & 120 & 11,0 & 120 & 11,0 & 10 & ,9 \\
\hline $\begin{array}{l}\text { 18- In TRHRK course, the inadequacy of } \\
\text { materials and hardware (or software) in } \\
\text { instructional technologies and other } \\
\text { materials is one of the problems faced. }\end{array}$ & 1090 & 4,0183 & 1,05828 & 420 & 38,5 & 450 & 41,3 & 60 & 5,5 & 140 & 12,8 & 20 & 1,8 \\
\hline $\begin{array}{l}\text { 17- The fact that in TRHRK course, Social } \\
\text { studies class (Branch Class) cannot be } \\
\text { formed as a single class negatively affects } \\
\text { acquisition of attainments and students' } \\
\text { success. }\end{array}$ & 1090 & 3,7982 & 1,30535 & 440 & 40,4 & 290 & 26,6 & 160 & 14,7 & 100 & 9,2 & 100 & 9,2 \\
\hline $\begin{array}{l}\text { 15- Variance in students' socio-economic } \\
\text { conditions prevents study trips and } \\
\text { in-school activities for TRHRK course. }\end{array}$ & 1090 & 3,7615 & 1,32018 & 420 & 38,5 & 330 & 30,3 & 90 & 8,3 & 160 & 14,7 & 90 & 8,3 \\
\hline
\end{tabular}

\subsubsection{Quantitative Findings with Regard to Perception} and Attitude towards the Course and Other Factors

Quantitative Findings with regard to perception and attitude towards the course and other factors are presented in Table 8

$42,2 \%$ of the participants in the study stated that they totally agreed with the statement that "the difference between historical subjects told at home and taught at school leads to informational convergence and trust problem for the students", $32,1 \%$ stated that they agreed with it. The percentage of those who stated opposing view is $13,8 \%$. It was concluded qualitative finding that there is a difference between the versions of the historical topics talked about at home or in immediate environment and those at school causes informational convergence and trust problem in students was highly supported by the participants in the quantitative part ( $\mathrm{X}=4,0275)$.

While $47.7 \%$ of the participants in the study totally agree with the qualitative finding that because of ideological reasons there are differences between the versions of the historical events talked about at home or immediate environment and those taught at school is one of the problems social studies teachers face, $29,4 \%$ stated that they agree. While $38,5 \%$ of the participants totally agree with the qualitative finding that "in TRHRK course, the inadequacy of materials and hardware (or software) in instructional technologies and other materials is one of the problems faced", $41,3 \%$ stated that they agreed. $79,8 \%$ of the participants stated positive opinion and agreed with this qualitative finding. The percentage of those who agreed partially is $5,5 \%$. The percentage of those who stated opposing view is $14,6 \% .38,5 \%$ of the participants in the study totally agreed with the qualitative finding that variance in students' socio-economic conditions prevents study trips and in-school activities for TRHRK course, $30,3 \%$ stated that they agreed. $68,8 \%$ of the participants who took part in the quantitative study stated positive opinion and agreed with the qualitative finding. The percentage of those who partially agree is $8,3 \%$. The percentage of those who stated opposing view is $23,0 \%$.

\section{Discussion and Conclusions}

The study in line with the views of the participants was constructed under the following three themes: problems stemming from the inadequacy of the course time and intensity of the syllabus, the problems caused by the adoption of the Behaviorist approach instead of constructivism, and the problems caused by the perception and attitude towards the course and other factors. Under the light of the quantitative data collected via quantitative data collection tool developed based on qualitative data, it was concluded that qualitative data can be generalized.

It was stated by all the participants who participated the qualitative part of the study that it was impossible to finish the content (attainments, activities) in the syllabus of TRHRK course within the time allocated for the course. The finding obtained as a result of qualitative study was supported by all of the social studies teachers who took part 
in the quantitative part of the study, which revealed that this situation is a problem experienced throughout Turkey. This result is in parallel with the result of a study by Bingöl [8] that "the view that time allocated for this course is not enough is prevalent among teachers".

With regard to the intensity of the course syllabus, both qualitative and quantitative findings which indicate that it is not possible to cover the syllabus of the course in line with the principles of the constructivist approach within the weekly course hour allocated support each other. In a study by Karacaoğlu [51], it was stated that the biggest problem in renewed programs was time problem. In the study, the participants stated that in line with the constructivist approach number of weekly hours of the course was raised form 2 hours to 3 hours in 2008 by the Board of Education and Discipline and this continued up to 2010. However, in 2010 the unit titled as "Turkey after Ataturk: The Second World War and after" was added to the syllabus of the TRHRK course and weekly hours of the course was decreased from 3 to 2 . This decrease in weekly course hour led to the problem of finishing the syllabus and this problem caused teachers to have the anxiety of finishing the syllabus.

It was stated by Delen [24] that the topics of the recent area should be added to the syllabus. After this change was made, it was determined in a study by Adalar [2] that this change was responded positively by teachers. However, when the intensity of the content and the time allocated for the course are considered in combination, P5 summarized the problem by saying, "I cannot finish so many topics, I am not a Superman, I do not have supernatural powers".

It was determined that all the participants in the qualitative phase stated that it was impossible to finish the syllabus of the TRHRK course by observing the principles of the constructivist approach within the course time allocated. It was concluded that this qualitative finding is supported by all of the 1090 teachers in the quantitative sample. In other words, this finding can be generalized. In the literature, Brooks and Brooks [10], Jonassen [47], Tynjala [82], stated that the content of a course is to be considered and enough time is to be allocated so that a course can be taught according to the principles of the constructivist approach. Acun [1], Wulf \& Schave [86], stated that the scope and content of the syllabus and time is to be balanced very well. Even if the syllabus is designed according to constructivism, it is not possible to apply constructivism in the class if adequate time is not allocated or not very well planned $[42,45,64,67,84]$. In this context, decision makers should reconsider the balance between the time allocated for the course, the content, scope and intensity of the syllabus according the principles of the constructivist approach $[6,16,32,59,71,72,80]$.

The social studies teachers who took part in the study stated that the inadequacy of course time caused them to have the anxiety of finishing the syllabus of TRHRK course; therefore, they covered some attainments of the course in
Media Literacy and Citizenship and Democracy Education courses. It was revealed that when the inadequacy of the course time was combined with the students' desire to prepare for transition to secondary education, Social studies teachers started to use the hours of the courses from which questions are not asked in TEOG exam. This case which means that Citizenship and Democracy Education, Media Literacy courses are not taught seems to be an important finding of the study.

It was found that the qualitative finding that imbalance between the weekly hours of TRHRK course and the intensity of the syllabus causes lessons to be taught superficially was accepted $87,2 \%$ of the participants in the quantitative part. In particular, they stated that they could not spare enough time for topics including Çanakkale Victory, Congress and the Period of National Struggle which are regarded important by the participant teachers and believed to help the development of national consciousness and historical sensitivity. P6 summarizes the case defined as follows: "We continuously think about the topics about which questions can be asked on the exam, the things to be done. I mean we always think about transmitting knowledge." This qualitative finding was accepted by $91.8 \%$ of the participants in the quantitative part of the study, which indicates that it can be generalized.

Teachers adopt exam-based approach to prepare their learners for TEOG exam, and they digress from the assessment-evaluation means and methods of the constructivist approach and they taught the topics superficially and attached importance to attainments by categorizing them according to the possibility of "their being asked or not in the exam". This case conflicts with the assessment principles of the constructivist stated by Holt-Reynolds [43], Jonassen [48], Semerci [73]. Constructivists, who are opposed to teacher centered lessons, argue that in general individuals' construction of information or discovering it. According to the constructivists, teachers should guide students to discover scientific theories and historical events $[18,35,57,65,68$, 88]. However, qualitative and quantitative findings indicating that in TRHRK course teachers could not give enough voice to the students and taught teacher-centered lesson support each other.

In their studies, Bingöl [8], Gömcü [39] and Gülnahar [40] determined that narration is the most commonly used method in TRHRK course. The finding obtained in the scope of the first theme that inadequate number of course hours causes anxiety of finishing the syllabus. This anxiety is the most important factor for the adoption of expository teaching. Besides, it was concluded excessive number of students, inadequacy of physical conditions, lack of separate social studies class in some schools, inadequacy of materials and instructional software and hardware were determined as other factors that prevent the application of the constructivist approach and student-centered methods and techniques. In the studies by Adalar [2], 
Gençmehmetoğlu [38], Gömcü [39] and Yanpar-Şahin [87] similar studies were obtained. In constructivist classes, according to Gagnon and Collay [36] as learning takes place in a meaningful, unique and complex environment, unique learning activities by which students can make their own decisions, apply their own learning plan, monitor his/her own improvement and assess his/her own study. In this context $[10,13,29,30,33,34,35,36,48,54,55,59,63$, $71,80,81,82,85]$ it is important to make up the deficiencies stemming from physical conditions and environment and design constructivist classes.

In the study, it was found that besides economic and cultural problems caused by the differences between socio-economic levels of the students, bureaucratic obstacles prevent study trips or activities outside school. Especially, when socio-constructivist approach is adopted in the teaching of topics in history, experiencing in in the teaching of history and social studies indicated by Maxim [57] and Parker [65], building connection with real life indicated by Çınar, Teyfur and Teyfur [23], Postletwaite [70], Sunal \& Has [76], Maxim [57], Mercer [59], Tobias, \& Duffy [80] and organizing study trips with a researching and inquiring approach based on proofs are important. In this context, lack of study trips and activities outside school seems to be one of the important obstacles for the application of the constructivist approach.

Because of ideological differences participants, sometimes there are differences between versions of the historical topics told at home or in close environment and at school, which leads to information convergence and trust problem for the students. The fact that this qualitative finding was supported by $77 \%$ of the teachers in the quantitative phase indicates that this is an important problem faced in TRHRK course. Especially, when differences in knowledge and perception of history, history education and historical topics because of ideological, cultural and social are considered, there is a need for objective history teaching $[27,50,53,57,65,78,90]$. In this context, it is considered that it will be beneficial to research this problem with an objective point of view. Stradling [75], who reported that similar problems are seen in Europe as well, stated that there are a number of TV programs on the media and internet which have commercial and political concerns and students fail to assess the accuracy of information presented in such programs and this is an educational problem. As a result, even if the syllabus is designed according to constructivist approach, traditional, teacher-centered, based on information and memorization, and exam focused education, which is away from the principles of the constructivism continues because of the obstacles mentioned above.

In this study, the biggest obstacle for the teaching of TRHRK course according to the constructivist approach was the inadequacy of weekly hour allocated for the course. When the scope of the content and changes in the syllabus are considered, this issue is too important to disregard. In line with this, it is suggest that the relation between content and time be reconsidered by decision makers. However, teachers regard the problems related to the system. In this context, the current situation can also be understood as a justification and /or defense mechanism of the teachers for their attitudes. Besides, the categories that emerged in the study suggest that it is necessary to examine teachers' self-efficacies in terms of the application of constructivism. Finally, the claim that there is difference between the versions of historical event told at home and at school and the confusion that this situation causes in the minds of the learners and brings the content of current history syllabus up for discussion and make us question why the version of history told at home is different from official history.

\section{Note}

This study was produced from Master Thesis written by Yavuz KARADEMIR under the supervision of Asst. Prof. Dr. Selçuk Beşir DEMİR.

\section{REFERENCES}

[1] Acun, R. (2011). Curriculum development in history using systems approach. Educational Sciences: Theory \& Practice, 11(2) 823-838

[2] Adalar, H. (2010). Sosyal Bilgiler Öğretmenlerinin 8. Sinıf T.C İnkılap Tarihi ve Atatürkçülük Dersi Yeni Öğretim Programına İlişkin Görüşlerinin Değerlendirilmesi. Gaziosmanpaşa Üniversitesi, Sosyal Bilimler Enstitüsü, Illköğretim Anabilim Dalı, Sosyal Bilimler Bilim Dal, Yüksek Lisans Tezi.

[3] Alexander, R. (2003). Culture and pedagogy: International comparisons in primary education. United Kingdom: Blackwell Publishing.

[4] Balcı, A. (1995). Sosyal bilimlerde araştırma. Ankara: Ankara Üniversitesi Eğitim Bilimleri Fakültesi Yayınları.

[5] Bartholomew, D. J., Knott, M., \& Moustaki, I, (2011) Latent variable models and factor analysis: A unified approach. West Sussex: Wiley.

[6] Beal, C. M., \& Bolick, C. M. (2013). Teaching social studies in middle and secondary schools. New Jersey: Pearson.

[7] Bevevino, M. M., Dengel, J., \& Adams, K. (1999). Constructivist theory in the classroom. Clearing Hause, 72, 275-279

[8] Bingöl, M. (2009). İlköğretim İkinci Kademe 8. Sinıfta Okutulan Türkiye Cumhuriyeti İnkılap Tarihi ve Atatürkçülük Dersinin Öğretimi, Karșlașlan Sorunlar ve Çözüm Önerileri(Ağri İli Örneği). Selçuk Üniversitesi, Sosyal Bilimler Enstitüsü, İlkögretim Anabilim Dall, Sosyal Bilgiler Ögretmenliği Bilim Dalı, Yüksek Lisans Tezi

[9] Bodner, G.M. (1986). Constructivism: A theory of knowledge. Journal of Chemical Education, 63, 873-878.

[10] Brooks, G., \& Brooks M. G. (1993). In search of 
understanding: the case for constructivist classrooms. Alexsandria: The Association for the Supervision and Curriculum Development.

[11] Brown, T. A. (2006). Confirmatory factor analysis for applied research. New York: Guilford Pres.

[12] Brownlow, C. (2004). SPSS explained. London: Routledge.

[13] Bukova-Güzel, E. (2007). The effect of a constructivist learning environment on the limit concept among mathematics student teachers. Educational Sciences: Theory \& Practice, 7(3), 1155-1198.

[14] Bulling, D. (2005). Development of an instrument to gauge preparedness of clergy for disaster response work: A mixed methods study. Unpublished manuscript, University of Nebraska-Lincoln.

[15] Camkıran, T. M. (2011). 1981 ve 2006 Türkiye Cumhuriyeti İnkılap Tarihi ve Atatürkçülük 8.Sınıf Programlarına Göre Hazırlanmıs Ders Kitaplarının İçerik ve Kullanılabilirlik Açılarından Karşılaştırılması. Marmara Üniversitesi, Eğitim Bilimleri Enstitüsü, Sosyal Bilimler Anabilim Dall, Yüksek Lisans Tezi.

[16] Chen, C. (2003). A constructivist approach to teaching: implications in teaching computer networking. Information Technology, Learning and Performance journal, 21(2).

[17] Child, D. (2006). The essentials of factor analysis. London: Continuum International Publishing Group.

[18] Cooper, H., \& Dilek, D. (2007). A comparative study on primary pupils' historical questioning processes in Turkey and England: Empathic, critical and creative thinking. Educational Sciences: Theory \& Practice, 7(2), 684-726.

[19] Copley, J. ( 1992). The integration of teacher education and technology: A Constructivist model. In D. Carey, R. Carey, D. Willis \& S. Willis ( Eds),Tecbnology and teacher education (p. 681). Charlottesville VA: AACE.

[20] Creswell, J. W. (2013). Araştırma deseni (Çev Edt: Demir, S. B.). Ankara: Eğiten Kitap.

[21] Creswell, J. W., \& Pablo-Clark V. (2014). Karma yöntem araştırmaları (Çev Edt: Dede, Y. ve Demir, S. B.). Ankara: An1

[22] Creswell, J., \& Miller, D. (2000) 'Determining Validity in Qualitative Inquiry’, Theory Into Practice, 39(3): 124-130.

[23] Çınar, O., Teyfur, E., \& Teyfur, M. (2006). İlköğretim okulu öğretmen ve yöneticilerinin yapılandırmacı eğitim yaklaşımı ve programı hakkındaki görüsşleri. İnönü Üniversitesi Ĕ̆itim Fakültesi Dergisi, 7(11), 47-64.

[24] Delen, S. (2007). İlköğretim ve Ortaöğretimde Öğretmen Görüşlerine Göre Türkiye Cumhuriyeti İnkılap Tarihi ve Atatürkçülük Dersi'nin Ögrretinde Karşılaşılan Sorunlar ve Çözüm Önerileri. Gazi Üniversitesi, Eğitim Bilimleri Enstitüsü, Ortaögretim Sosyal Alanlar Ĕgitimi Anabilim Dall, Yüksek Lisans Tezi.

[25] Demirel, Ö. (2005). Eğitimde program geliştirme: Kuramdan uygulamaya (8. Baskr.). Ankara: PegeamA

[26] Dilek, D. (1999). History in the Turkish elementary school: Perceptions and pedagogy. Unpublished doctorate dissertation, The University of Warwick, Coventry.
[27] Dinç, E. (2001). The influence of politics on history teaching. Unpublished master's thesis, The University of Leicester, Leicester.

[28] Dinç, E. (2011). A comparative investigation of the previous and new secondary history curriculum: The issues of the definition of the aims and objectives and the selection of curriculum content. Educational Sciences: Theory \& Practice, 12(1), 271-299.

[29] Eggen, P., \& Kauchak, D. (2001). Educational Psychology: windows on classrooms. Upper Saddle River, NJ.: Prentice Hall.

[30] Ernst, P. (1995). The one and the many. In L. Steffe \& J. Gale (Eds.). Constructivism in education (pp. 459-486). New Jersey: Lawrence Erlbaum Associates.

[31] Fabrigar, L. R. \& Wegener. D. T. (2011). Exploratory factor analysis. Oxford: Oxford University Pres.

[32] Fensham, P. J., Gunstone, R. F., \& White, R. T. (1994). Science content and constructivist views of learning and teaching. In P. J. Fensham, R. F. Gunstone \& R. T. White (Eds.), The content of science (pp. 1-8). London: The Falmer Press

[33] Fox, R. (2001). Constructivism examined. Oxford Review of Education. 27, 33-39.

[34] Gabler, I. C., \& Schroeder, M. (2003). Constructivist methods for the secondary classroom: Engaged minds. New Jersey: Pearson.

[35] Gagnon G. W., \& Collay, M, (2005). Constructivist learning design. Thousand Oaks, CA: Sage.

[36] Gagnon, G. W. \& Colloy, M. (2001). Designing for learning: Six elements in constructivist classrooms. Thousand Oaks, CA: Corwin Press.

[37] Gencer, H. (2007). İlköğretim TC İnkılap Tarihi ve Atatürkçülük Dersinde Amaç Gerçekleştirme Başarısına İlişkin Öğretmen Görüşlerinin Değerlendirilmesi(Diyarbakır Örneği). Dicle Üniversitesi, Sosyal Bilimler Enstitüsü, Ĕ̈itim Bilimleri Eğitimi Anabilim Dalı, Eğitim Programları ve Öğretimi Bilim Dal, Yüksek Lisans Tezi.

[38] Gençmehmetoğlu, R. (2009). VIII. Sinıf Türkiye Cumhuriyeti Inkılap Tarihi ve Atatürkçülük Dersinde Yer Alan Olgu, Kavram ve Genellemelerin Öğretimi ve Önemi. Erzurum: Atatürk Üniversitesi, Sosyal Bilimler Enstitüsü, İlköğretim Anabilim Dalı, Yüksek Lisans Tezi.

[39] Gömcü, B. (2006). İlköğretim 8. Sinıf T.C Inkılap Tarihi ve Atatürkçülük Dersi'nin Kurtuluş Savaşı Dönemi Ünitesinin İşlenişinde Karşılaşılan Problemlere İlişkin Öğretmen ve Ögrrenci Görüşleri. Ankara: Gazi Üniversitesi, Eğitim Bilimleri Enstitüsü, Sosyal Bilgler Eğitimi Anabilim Dalı, Yüksek Lisans Tezi.

[40] Gülnahar, F. (2012). Sosyal Bilgiler Öğretmen Adaylarının Lisans Ĕgitimlerinde Gördükleri Atatürk Illkeleri ve İnklap Tarihi Dersine Yönelik Tutumların Değerlendirilmesi (Erzincan Üniverisitesi Örneği). Erzincan: Erzincan Üniversitesi, Sosyal Bilimler Enstitüsü, Sosyal Bilgiler Eğitimi Anabilim Dalı, Yüksek Lisans Tezi.

[41] Harnett, P. (2000). Primary in the primary school; re-shaping our pasts. The influence of primary school teachers' 
596 The Obstacles for the Teaching of 8th Grade TR History of Revolution and Kemalism Course According to the Constructivist Approach (An Example of Exploratory Sequential Mixed Method Design)

knowledge and understanding of history on curriculum planning and implementation. International Journal of Historical Learning, Teaching and Research, 1(1), 14-18.

[42] Hesapçıŏlu, M. (2008). Öğretim ilke ve yöntemleri: Ĕ̆itim programlarl ve ögretim. Ankara: Nobel.

[43] Holt-Reynolds, D. (2000). What does the teacher do? Constructivist pedagogies and prospective teachers' beliefs about the role of a teacher. Teaching and Teacher Education, $16,21-32$.

[44] Hutcheson, G. D. \& Sofroniou, N. (1999). The Multivariate social scientist: introductory statistics using generalized linear models. Thousand Oaks, CA: Sage.

[45] Ingersoll, R. M. (2007). Short on power long on responsibility. Educational Leadership, 65(1), 20-25.

[46] Jadallah, E. (2000) Constructivist learning experience for social studies education. The Social Studies, 9, 221-225.

[47] Jonassen, D. H. (1990). Thinking technology: Toward a constructivist view of instructional design. Educational Technology, 30(9), 32-34.

[48] Jonassen, D. H. (1992). Evaluating constructivist learning. In T. M. Duffy \& D.H. Jonassen (Eds.), (pp.137-147). London: Lawrence Erlbaum.

[49] Jonassen, D., H. (1991). Evaluating constructivistic learning. Educational Technology, 31, 28-33.

[50] Kabapınar, Y. (1992). Bir ideolojik mücadele alanı olarak tarih ders kitapları. Tarih ve Toplum, 107, 284-287.

[51] Karacaoğlu, Ö. C., \& Acar, E. (2010). Yenilenen programların uygulanmasında öğretmenlerin karşılaştıkları sorunlar. yüzüncü Yll Üniversitesi, Eğitim Fakültesi Dergisi, $7(1), 45-58$.

[52] Karadağ, E. (2007). Development of teachers' sufficiency scale in relation to constructivist learning: Reliability and validity analysis. Educational Sciences: Theory \& Practice, $7(1), 152-175$.

[53] Kaya, H., Kahyaoğlu, D., Çetiner, A., Öztürk, M., \& Eren, N. (2001). National report of Turkey. In Improvement of Balkan history textbooks project report (pp. 155-184). İstanbul: The Economic and Social History Foundation of Turkey.

[54] Kim, H. B., Fisher, L. D., \& Fraser, J. B. (1999). Assessment and investigation of constructivist science learning environment in Korea. Research in Science and Technological Education, 17(2), 239-24.

[55] Marlowe. B. A. \& Page, M. L. (2005). Creating and sustaining the constructivist classroom. Thousand Oaks, CA: Sage

[56] Marshall, C., \& Rossman, G. B. (2011). Designing qualitative research (4th ed.). Thousand Oaks, CA: Sage.

[57] Maxim, G. W. (2013). Dynamic social studies for constructivist classrooms: Inspiring tomorrow's social scientist. New Jersey: Pearson.

[58] MEB. (2007). Tarih Dersi Öğretimi Programı (9. Sinıf). Ankara: MEB Talim ve Terbiye Kurulu Başkanlığı.
[59] Mercer, N. (1995). The guided construction of knowledge. Clevedon, U.K.: Multilingual Matters

[60] Miles, M. B., \& Huberman, A. M. (1994). Qualitative data analysis: An expanded sourcebook (2nd ed.). Thousand Oaks, CA: Sage.

[61] Morse, J. M. (2003). Principles of mixed methods and multimethod research design. In A. Tashakkori \& C. Teddlie (Eds.), Handbook of mixed methods in social \& behavioral research (pp. 189-208). Thousand Oaks, CA: Sage.

[62] Myers, K. K., \& Oetzel, J. G. (2003). Exploring the dimensions of organizational assimilation: Creating and validating a measure. Communication Quarterly, 51(4), $438-457$.

[63] Naylor, S. (1999). Constructivism in classroom: Theory into practice. Science Teacher Education, 10(2), 93106.

[64] Öztürk, İ. H. (2012). Teacher's role and autonomy in instructional planning: The case of secondary school history teachers with regard to the preparation and implementation of annual instructional plans. Educational Sciences: Theory \& Practice, 11(4), 2135-2153.

[65] Parker, C. W. (2012) Social studies in elementary education. New Jersey: Pearson.

[66] Patton, Q. M. (2014) Nitel araştırma ve değerlendirme yöntemleri (Çev Edt: Bütün, M. ve Demir, S. B). Ankara: PegemA

[67] Pearson, L. C., \& Moomaw, W. (2005). The Relationship between teacher autonomy and stress, work satisfaction, empowerment, and professionalism. Educational Research Quarterly, 29(1), 37-53.

[68] Perkins, D. (1999). The many faces of constructivism. Educational Leadership, 57(3), 6-11.

[69] Pett, M. A., Lackey, N. R., \& Sullivan, J. J. (2003). Making sense of factor analysis: The use of factor analysis for instrument development in health care research. Thousand Oaks, CA: Sage.

[70] Postlethwaite, K. (1993). Differentiated science teaching. Philadelphia: Open University Press.

[71] Richardson, V. (1997). Constructivist teacher education: building a world of new understandings. New York: Routledge.

[72] Schunk, D. H. (2004). Learning theories: An educational perspective. New Jersey: Prentice Hall Inc.

[73] Semerci, Ç. (2001). Measurement and evaluation according to constructivist theory. Educational Sciences: Theory \& Practice, 1(2), 429-440.

[74] Sherman, J.S. (2000). Science and science teaching. Boston: Houghton Mifflin.

[75] Stradling, R. (2003). 20. Yüzyıl Avrupa tarihi nasıl ögretilmeli. İstanbul: Tarih Vakfi.

[76] Sunal, C. S., \& Has. M. E. (2011) Social studies for the elementary and middle grades: A constructivist approach. New Jersey: Pearson.

[77] Talim Terbiye Kurulu Başkanlığı. (2006). Türkiye 
Cumhuriyeti İkılap Tarihi ve Atatürkçülük Dersi 8. Sinıf Programı. Ankara: T.C Milli Eğitim Bakanlığı.

[78] Tekeli, İ. (1998). Tarih bilinci ve gençlik. İstanbul: Tarih Vakfı Yurt Yayınları.

[79] Thompson, B. (2004). Exploratory and confirmatory factor analysis. Washington, DC: American Psychological Association Pres

[80] Tobias, S., \& Duffy, T. M. (Eds.). (2009). Constructivist instruction: Success or failure? New York: Routledge.

[81] Tsai, C. C. (2000). Relationships between student scientific epistemological beliefs and perceptions of constructivist learning environments. Educational Research, 42, 193-205.

[82] Tynjala, P. (1999). Traditional studying for examination versus constructivist learning tasks: Do learning outcomes differ? Studies in Higher Education, 23(2), 173-190.

[83] Walkey, F., \& Welch, G. (2010) Demystifying factor analysis: How it works and how to use it. Bloomington: Xlibris, Corp.

[84] Webb, P. T. (2002). Teacher power: The exercise of professional autonomy in an era of strict accountability.
Teacher Development, 6(1), 47-62.

[85] Willis, J. W. (2009). Constructivist instructional design (C-ID). Charlotte: Information Age Publishing.

[86] Wulf, K. M., \& Schave, B. (1984). Curriculum design: A handbook for educators. California: Scott, Foresman and Company.

[87] Yanpar-Şahin, T. (2001). The effect of constructivist approach on cognitive and affective learning in social studies course. Educational Sciences: Theory \& Practice, 1(2), 463-482.

[88] Yeager, E. A., \& Foster, S. J. (2001). The role of emphaty in the development of historical understanding. O. L. Davis Jr., E. Anneyeager, S. J. Foster (Ed), Historical Empathy and Perspective Taking in the Social Studies (pp. 13-21). USA: Rowman \& Little Field.

[89] Yıldırım A,, \& Şimşek H. (2013). Sosyal bilimlerde nitel araştırma yöntemleri. Ankara: Seçkin.

[90] Zarrillo, J. J. (2012). Teaching elementary social studies: Principles and applications. New Jersey: Pearson. 